\title{
Mesothelial Neoplasm
}

National Cancer Institute

\section{Source}

National Cancer Institute. Mesothelial Neoplasm. NCI Thesaurus. Code C3786.

A benign or malignant neoplasm arising from mesothelial cells. Mesothelial cells are the

lining cells of the pleura and peritoneum. -- 2003 